\title{
Eterno retorno (Apokatastasis)
}



Verbete do Wörterbuch der Philosophie Neue Beiträge zu einer Kritik der Sprache (Dicionário de filosofia - Novas contribuições a uma crítica da linguagem), de Fritz Mauthner. Viena: Böhlau, 1997, v. 1.

Apokatastasis - restitutio, restauração geral, retorno do mesmo, ou como quer que se queira traduzir a palavra grega -, este conceito já quase não faria parte de um dicionário filosófico do presente, se a fama de Nietzsche não tivesse ajudado a popularizar alguns caprichos e pensamentos obscuros, pensamentos, além disso, aforismáticos, na forma irresponsável que os editores do espólio escolhem como bem entendem entre aquilo que deixou. Mas agora os mais jovens e leitores de Nietzsche falam tão familiarmente do eterno retorno, como se essa doutrina fosse mais do que uma fábula antiquíssima. O filólogo Nietzsche sabia muito bem que essa fábula, que nos soa hindu, já havia sido contada por Heráclito (e talvez também por Pitágoras), e que os estoicos já lhe haviam acrescentado os traços quase realistas do retorno dos exatamente mesmos acontecimentos e pessoas após cada crepúsculo dos deuses (ekpurosis); filho de pastor, Nietzsche sabia provavelmente que os Atos dos Apóstolos (3, 21) falam da apokatastasis panton (na Vulgata: restitutio omnium) que essa crença, que talvez significasse apenas a ressurreição da carne, foi desenvolvida por Orígenes mais no sentido dos estoicos, e que a fé na restitutio universalis voltava sempre a encontrar, de longe em longe, seitas crédulas, a última delas nos Estados Unidos, sob o nome de universalismo. É uma crença tão brutalmente materialista, que, comparada a ela, o céu demasiadamente terreno de Maomé parece quase idealista.

Nietzsche fundamentou tão pouco e tão mal sua fantasia sobre o eterno retorno, que uma refutação parece supérflua. Apenas algumas palavras. Sua imagem da ampulheta é equivocada. 
"Homem! Toda a sua vida será sempre virada de novo como uma ampulheta e voltará de novo a findar - um intervalo de um grande minuto de tempo até que todas as condições a partir das quais você surgiu novamente se juntem na revolução cíclica do mundo." Nietzsche esqueceu-se de que o que pode ser medido na ampulheta é somente o tempo, que não retorna, e de que, no entanto, justamente as condições da vida individual e os fluxos da vida física e psíquica não podem ser de modo algum revertidos. Ela seria apenas uma imagem falsa. Nietzsche ainda se esqueceu, porém, de que ele computa o retorno das mesmas situações a partir da infinidade do tempo e da finidade do número de combinações de átomos, de que 1) dada a pequenez dos átomos e moléculas, as meras combinações de átomos de um único corpo humano perfariam um número que não poderia diferenciar infinitamente nenhuma representação humana da representação humana; de que 2) moléculas e átomos são fichas de jogo da alta química, conceitos-limite com a operação dos quais todo filósofo deveria se ressabiar, e mais ainda o filósofo moral; de que 3) o recurso à extensão infinita do tempo já transcorrido (o qual, portanto, já haveria de ter esgotado todas as combinações ou ter atingido por entropia o estado de equilíbrio prenunciado) é tão facilmente corrigido pela duração posterior do tempo, como a negação sofística do conceito de movimento pelo caminhar de Diógenes. Acerca da exploração moral do eterno retorno para uma religião das almas mais livres, mais alegres e mais sublimes, já fiz a seguinte observação (Crítica da linguagem, I, p. 365): "Se Nietzsche opõe à regra moral de Kant a máxima altaneira: Viva como se, em vista do eterno retorno, você quisesse viver um sem-número de vezes!, ele esquece por completo que aqui justamente o peso de suas ideias e sua influência sobre as ações dos homens simplesmente anulariam o retorno do mesmo". Acredito ter sido claro. Se a crença no eterno retorno pudesse tornar-se moral, isto é, prática, se por meio dessa crença um único alento pudesse resultar diferente do que sem essa crença, então o retorno exato do mesmo 
estaria destruído, o objeto da crença seria aniquilado - o que, sem dúvida, pode por vezes ocorrer.

No enorme poema de seu Zaratustra, Nietzsche deu uma nova expressão poética à antiga fantasia do eterno retorno, e contra isso só um filisteu teria algo a objetar. No reino da poesia, também essa representação tem seu lugar. Assim como no reino de um misticismo religioso. No pensamento, no pensamento com palavras razoavelmente claras, ela é incabível; ela é uma fábula antiquíssima, mas não uma bela fábula. Uma bela fábula é a representação da imortalidade da alma, tão bela, que um Goethe gostava de jogar com a imagem e, nas horas de mística, talvez acreditasse seriamente na imortalidade de almas aristocráticas privilegiadas, por exemplo, a própria. A representação do eterno retorno é a caricatura mais execrável do determinismo que se possa imaginar. Imaginem: no intervalo de um grande minuto de tempo, Nietzsche está de novo frequentando a escola e a universidade, se torna novamente professor, sofre de novo de indizíveis dores de cabeça e da alma, atormenta novamente seu cérebro polindo e repolindo aforismos, é mais uma vez acometido de loucura, e sua irmã, que também vive mais uma vez, tira novamente do seu espólio os andrajos do eterno retorno. E os editores filológicos se pegam de novo pelos cabelos. Não haveria como não se tornar pessimista. 
